\title{
The effect of mercury, copper, and zinc on paraoxonase (PON) enzyme activity in Bonito (Sarda sarda) fish
}

\section{Palamut (Sarda sarda) balığında paraoksonaz (PON) enzim aktivitesi üzerine cıva, bakır ve çinkonun etkisi}

\author{
Büşra Şahin ${ }^{*}$ • Sena Çenesiz² \\ ${ }^{1}$ Department of Veterinary Biochemistry, Faculty of Veterinary Medicine, Ondokuz Mayis University, \\ Samsun, Turkey \\ ${ }^{2}$ Department of Veterinary Biochemistry, Faculty of Veterinary Medicine, Ondokuz Mayis University, \\ Samsun, Turkey
}

\section{How to cite this paper:}

Şahin, B. \& Çenesiz, S. (2021). The effect of mercury, copper, and zinc on paraoxonase (PON) enzyme activity in Bonito (Sarda sarda) fish. Ege Journal of Fisheries and Aquatic Sciences, 38(4), 479-486. DOI: 10.12714/egejfas.38.4.09

Abstract: Since heavy metal dirtiness, which we frequently encounter in environmental pollution causes harmful effects on the organism through biochemical enzyme reactions, in this study, the effects of mercury $\left(\mathrm{Hg}^{+2}\right)$, copper $\left(\mathrm{Cu}^{+2}\right)$, and zinc $\left(\mathrm{Zn}^{+2}\right)$ heavy metal ions, which are common in environmental pollution, on PON (paraoxonase) enzyme activity in muscle tissue of bonito (Sarda sarda) were investigated. In the study, 25 bonito (S. sarda) fish muscle tissues freshly obtained from the Samsun region sea were used. The changes in PON enzyme activity were determined by adding different volumes of heavy metal solutions. PON enzyme activities of $\mathrm{Hg}^{+2}$ heavy metal ion used in different volumes were calculated as $30.9383 \mathrm{U} / \mathrm{mLdak}$, $29.0598 \mathrm{U} / \mathrm{mLdak}, 26.3799 \mathrm{U} / \mathrm{mL}$ dak, $23.9443 \mathrm{U} / \mathrm{mL}$ dak, $20.6725 \mathrm{U} / \mathrm{mLdak}$, PON enzyme activities of $\mathrm{Cu}^{+2}$ heavy metal ion used in different volumes were calculated as $19.7949 \mathrm{U} / \mathrm{mLdak}, 19.4807 \mathrm{U} / \mathrm{mLdak} 19.1864 \mathrm{U} / \mathrm{mLdak}, 19.1200 \mathrm{U} / \mathrm{mLdak}, 18.9037 \mathrm{U} / \mathrm{mLdak}$ and PON enzyme activities of Zn $\mathrm{n}^{+2}$ heavy metal ion used in different volumes were calculated as $23.8305 \mathrm{U} / \mathrm{mLdak}, 23.0781 \mathrm{U} / \mathrm{mLdak}, 22.9073 \mathrm{U} / \mathrm{mLdak}, 22.4324 \mathrm{U} / \mathrm{mLdak}, 21.8159 \mathrm{U} / \mathrm{mLdak}$. As a result of these obtained data, activity $(\%)$ values were calculated and activity (\%) graphs were drawn. As a result of the study, it was determined that increasing concentrations of $\mathrm{Cu}^{+2}$ and $\mathrm{Zn}^{+2}$ heavy metal ions caused a decrease in PON enzyme activity, but there was no statistically significant difference between the different concentrations used. It was determined that increasing concentrations of $\mathrm{Hg}^{+2}$ heavy metal ion inhibited the PON enzyme activity, caused a statistically significant decrease between the activities depending on the different concentrations used $(p<0.05)$.

Keywords: Bonito (Sarda sarda), heavy metals, copper (Cu), mercury $(\mathrm{Hg})$, zinc $(\mathrm{Zn})$, paraoxonase (PON)

Öz: Çevre kirliliğinde sık rastlanan ağır metal kirlilikleri, biyokimyasal enzim reaksiyonları üzerinden organizmada zararlı etkiler meydana getirdiği için bu çalışmada çevre kirliliğinde sık rastlanan cıva $\left(\mathrm{Hg}^{+2}\right)$, bakır $\left(\mathrm{Cu}^{+2}\right)$ ve çinko $\left(\mathrm{Zn}^{+2}\right)$ ağır metal iyonlarının palamut (Sarda sarda) balığı kas dokusunda bulunan PON (paraoksonaz) aktivitesi üzerine etkileri araştırımışıı. Çalışmada Samsun bölgesi denizinden taze olarak temin edilen 25 adet palamut balığının kas dokuları kullanıldı. Ağır metal çözeltilerinden farklı hacimlerde eklenerek PON enzim aktivitesindeki değişiklikler tayin edildi. Farklı hacimlerde kullanılan $\mathrm{Hg}^{+2}$ ağır metal iyonunun PON enzim aktiviteleri 30,9383 U/mLdak, 29,0598 U/mLdak, 26,3799 U/mLdak, 23,9443 U/mLdak, 20,6725 U/mLdak olarak hesaplandı, farklı hacimlerde kullanılan $\mathrm{Cu}^{+2}$ ağır metal iyonunun PON enzim aktiviteleri 19,7949 U/mLdak, 19,4807 U/mLdak 19,1864 U/mLdak, 19,1200 $\mathrm{U} / \mathrm{mLdak}, 18,9037 \mathrm{U} / \mathrm{mL}$ dak olarak hesaplandı ve farklı hacimlerde kullanılan $\mathrm{Zn}^{+2}$ ağır metal iyonunun PON enzim aktiviteleri 23,8305 U/mLdak, 23,0781 $\mathrm{U} / \mathrm{mL}$ dak, 22,9073 U/mLdak, 22,4324 U/mLdak, 21,8159 U/mLdak olarak hesaplandı. Elde edilen bu veriler sonucunda \% aktivite değerleri hesaplanarak \% aktivite grafikleri çizildi. Çalışma sonucunda $\mathrm{Cu}^{+2}$ ve $\mathrm{Zn}^{+2}$ ağır metal iyonlarının artan derişimlerinin enzim aktivitesinde azalmaya neden olduğu fakat kullanılan farkı derişimler arasında istatistiksel olarak anlamlı bir fark olmadığı belirlendi. $\mathrm{Hg}^{+2}$ ağır metal iyonun artan derişimlerinin PON enzim aktivitesini inhibe ettiği, kullanılan farkı derişimlere bağı olarak aktiviteler arasında istatistiksel olarak anlamlı bir azalmaya neden olduğu belirlendi $(p<0.05)$.

Anahtar kelimeler: Palamut (Sarda sarda), ağır metal, bakır (Cu), cıva ( $\mathrm{Hg})$, çinko (Zn), paraoksonaz (PON)

\section{INTRODUCTION}

Paraoxonase (PON) is a serum esterase with arylesterase and paraoxonase activities (aryldialkylphosphatase; E.C.3.1.8.1), which is expressed from the liver and able to hydrolyze paraoxone, which the active metabolite of parathion (Primo-Parma et al., 1996; Memişoğulları and Orhan, 2010). The paraoxonase enzyme hydrolyzes toxic oxon metabolites of insecticides such as chlorpyrifos, parathion, and diazinon (Mackness et al., 1996), OP (organophosphate) nerve agents such as sarin, tabun, and soman (Broomfield and Ford, 1991; Baillie et al., 1993), and ester substrates such as phenylacetate (Eckerson et al., 1983; Sorenson et al., 1995). The gene which is responsible for PON activity has three members and is called PON1, PON2, PON3 (Primo-Parma et al., 1996). After PON1 and PON3 are synthesized in the liver, they are delivered to the blood, the plasma is transported together with HDL (high density lipoprotein). PON2, on the other hand, is not found in serum and synthesized in many different tissues (Teiber et al., 2007). It has been hypothesized that the receptor that provides the relationship between PON and HDL is scavenger 
receptor B1 (SR-B1). It has been reported that this receptor $\mathrm{HDL}$ binding to the membrane of the cell and providing material exchange between the cell and lipoproteins and that PON is synthesized abundantly from the liver (Deakin and James, 2004).

There are many defense mechanisms to prevent the formation of reactive oxygen species (ROT) in living and the damage which is caused (Prior and Cao, 1999). One of them is the PON enzyme (Costa et al., 1999; La Du et al., 1999). The paraoxonase enzyme exists depending on HDL and has a protective effect against the formation of lipid peroxides by oxidation of LDL (low density lipoprotein) (Mackness et al., 2001; Carey et al., 2005). It shows an antioxidant property by limiting lipid oxidation in LDL thanks to HDL, which is dependent on the structure of this enzyme (Elana et al., 2006).

Heavy metals are defined as metals which have toxic or poisoner effects even at low concentration and they have a density of more than $5 \mathrm{~g} / \mathrm{cm}^{3}$ in terms of physical properties (Kahvecioğlu et al., 2003; Seven et al., 2018). These metals, even if found in small quantities, accumulate in the body of aquatic organisms at increasing rates and reach levels that will do a toxic effect (Ikuta, 1985). Although some metals, like copper and iron, are necessary for life at certain levels, metals in the state of mercury and lead can be toxic even at trace levels $(\mathrm{Hu}, 2002)$. Heavy metals are taken from the external environment by fish and are transported to tissues and organs through the blood tract by binding with carrier proteins, reaching high concentrations holding by metalretaining proteins in tissues (Kaptan, 2014). Metals of physiological importance are stored from metals that can be excreted out of the body by participating in different metabolic processes in the living structure, but if these are toxic metals, these can disrupt enzyme structures (Yazkan et al., 2004). Mercury $(\mathrm{Hg})$ levels in the tissues of fish found in these regions have also increased due to the increase of industrial enterprises on the sea coast (Vural, 1993). Hg is highly toxic to fish, even in very low amounts. Organic $\mathrm{Hg}$ compounds usually enter the living body through food, causing chronic toxic disorders after accumulating (Dökmeci, 2001; Kaya and Akar, 2002). Copper (Cu) is taken from the environment by fish usually through the gill and food, its excretion outside the body is through feces and urine (Sağmanlıgil, 1994; Cicik, 2003). Excess copper in the water accumulates in the gill tissue within a short period, as well as reaching higher concentrations in the liver tissue depending on the duration of action (Kalay and Erdem,1995). Besides, the Cu metal increases the outflow of sodium ions by fracking the energybound sodium/potassium pump in the gill tissue (Cicik, 2003; Coppock and Nation, 2007). In addition to the fact that the mechanism of action of zinc ( $\mathrm{Zn}$ ) metal in fish is not fully known, it has been found to cause damage to gill tissue (Cicik, 2003; Kaya and Akar, 2002; Ağcasulu, 2007).

Heavy metals, which reach from the first step to the last step of the food chain and showing accumulation, in bonito
(S. sarda Bloch, 1793) fish, which is of great importance in protein-rich human nutrition, the accumulation in increasing concentrations shows a toxic effect and negatively affects human health. To find a solution to such a problem, further research of some metals is needed. How the activity of the PON enzyme with physiological function in metabolism, is affected by some heavy metals is extremely important for animal and environmental health. This study has investigated the effects of mercury $\left(\mathrm{Hg}^{+2}\right)$, copper $\left(\mathrm{Cu}^{+2}\right)$, and zinc $\left(\mathrm{Zn}^{+2}\right)$ heavy metal ions on PON enzyme activity in muscle tissue of bonito (S. sarda) fish.

\section{MATERIAL AND METHODS}

A total of 25 bonito (S. sarda) fish, which an average weight of $600-800 \mathrm{~g}$ and a length of 40 to $45 \mathrm{~cm}$ consisted of the material of the study. In the study, muscle tissue of bonito (S. sarda) fish freshly taken from the sea of Samsun region in October, which is the seasonal season of this fish species, and brought to the laboratory environment by the cold chain in a short time was used. Tissue samples taken from bonito ( $S$. sarda) were weighed $0.3 \mathrm{~g}$ and taken into dry centrifuge tubes, then $1.5 \mathrm{~mL}$ Tris- $\mathrm{HCl}$ buffer was added to them and homogenized. The homogenized tissues were centrifuged in a cooled centrifuge at $+4{ }^{\circ} \mathrm{C}$ and $3000 \mathrm{rmp}$ speed for 30 minutes and supernatants were separated. Then, the separated supernatants were used on the same day.

PON enzyme activity determination method recommended by Gülcü and Gürsu (2003), was used for PON enzyme activity determination. In activity determination, $50 \mu \mathrm{L}$ Tris- $\mathrm{HCl}$ buffer, $50 \mu \mathrm{L}$ substrate (calcium chloride+paraoxone) solution were added to cuvettes and the value at $405 \mathrm{~nm}$ absorbance was read in ELISA. $50 \mu \mathrm{L}$ supernatant solution was added to the measured cuvettes and the change occurring in the absorbance at $405 \mathrm{~nm}$, at 37 ${ }^{\circ} \mathrm{C}$ in ELISA it was read in 30 seconds. In this way, the enzymatic conversion speed of paraoxone to $p$-nitrophenol was defined as PON activity (1 U/L).

The activity measurement in the paraoxonase enzyme of the mercury II chloride $\left(\mathrm{HgCl}_{2}\right)$ solution: In paraoxonase enzyme activity determination, $50 \mu \mathrm{L}$ tris-HCL buffer, $50 \mu \mathrm{L}$ substrate (calcium chloride+paraoxone) solution, and $50 \mu \mathrm{L}$ supernatant solution were added to the cuvettes, and the value at $37^{\circ} \mathrm{C}$ and $405 \mathrm{~nm}$ absorbance in ELISA it was read in 30 seconds. Then, the change in enzyme activity was determined, after adding different volumes $10 \mu \mathrm{L}, 20 \mu \mathrm{L}, 30$ $\mu \mathrm{L}, 40 \mu \mathrm{L}, 50 \mu \mathrm{L} 0.001 \mathrm{M} \mathrm{HgCl}_{2}$ solution to the measuring cuvette. The enzyme activity determined in the environment without inhibitor was used as $100 \%$ activity.

The activity measurement in the paraoxonase enzyme of the copper II chloride $\left(\mathrm{CuCl}_{2}\right)$ solution: In paraoxonase enzyme activity determination, $50 \mu \mathrm{L}$ tris-HCL buffer, $50 \mu \mathrm{L}$ substrate (calcium chloride+paraoxone) solution, and $50 \mu \mathrm{L}$ supernatant solution was added to the cuvettes and the value at $37^{\circ} \mathrm{C}$ and $405 \mathrm{~nm}$ absorbance in ELISA it was read in 30 seconds. Then, the change in enzyme activity was 
determined, after adding different volumes $10 \mu \mathrm{L}, 20 \mu \mathrm{L}, 30$ $\mu \mathrm{L}, 40 \mu \mathrm{L}, 50 \mu \mathrm{L} 0.001 \mathrm{M} \mathrm{CuCl}_{2}$ solution to the measuring cuvette. The enzyme activity determined in the environment without inhibitor was used as $100 \%$ activity.

The activity measurement in the paraoxonase enzyme of the zinc II chloride $\left(\mathrm{ZnCl}_{2}\right)$ solution: In paraoxonase enzyme activity determination, $50 \mu \mathrm{L}$ tris-HCL buffer, $50 \mu \mathrm{L}$ substrate (calcium chloride+paraoxone) solution, and $50 \mu \mathrm{L}$ supernatant solution were added to the cuvettes, and the value at $37^{\circ} \mathrm{C}$ and $405 \mathrm{~nm}$ absorbance in ELISA it was read in 30 seconds. Then, the change in enzyme activity was determined, after adding different volumes $10 \mu \mathrm{L}, 20 \mu \mathrm{L}, 30$ $\mu \mathrm{L}, 40 \mu \mathrm{L}, 50 \mu \mathrm{L} 0.001 \mathrm{M} \mathrm{ZnCl}_{2}$ solution to the measuring cuvette. The enzyme activity determined in the environment without inhibitor was used as $100 \%$ activity.

Measurement of the total oxidant capacity (TOC): The TOC was measured by a colorimetric method based on the cumulatively oxidize of ferrous ion to the ferric ion of oxidant molecules present in the supernatant (Erel, 2004, 2005). Calculations were made according to the formula in the procedure.

Measurement of the total antioxidant capacity (TAC): The TAC was measured by the method of decolorization of the colored radical in proportion to the total concentration of the antioxidant molecules by reducing dark blue-green colored ABTS cationic radical of all antioxidant molecules present in the supernatant (Erel, 2004, 2005). Calculations were made according to the formula in the procedure.

Calculation of the oxidative stress Index (OSI): The OSI was obtained by calculating from the Total oxidant capacity ( $\mu \mathrm{mol} \mathrm{H}_{2} \mathrm{O}_{2}$ Equiv/L)/Total antioxidant capacity (mmol TroloxEquiv/L) $\times 10$ formulation.

SPSS statistical (version 22) package program was used for statistical analysis. The analysis of the samples was done with a One-Way Analysis of Variance (One-Way Anova). While the difference between the samples was not significant for $p>0.05$ value, the difference was regarded to be significant for $p<0.05$ value. For the samples with a value of $p<0.05$, the homogeneity of the samples was examined using the homogeneity of variance test, and the samples with a significant difference between them were compared with the Tukey test.

\section{RESULTS}

The enzyme activity table and graph were drawn by repeating the measurements made by taking different volumes from $\mathrm{CuCl}_{2}, \mathrm{HgCl}_{2}$, and $\mathrm{ZnCl}_{2}$ solutions and studying in duplicate and calculating the average of the results.

Paraoxonase enzyme activity (\%) values obtained by using $\mathrm{HgCl}_{2}$ solutions of different concentrations $\left(0.6 \times 10^{-4} \mathrm{M}\right.$, $\left.1.1 \times 10^{-4} \mathrm{M}, 1.6 \times 10^{-4} \mathrm{M}, 2.1 \times 10^{-4} \mathrm{M}, 2.5 \times 10^{-4} \mathrm{M}\right)$ were given in Table 1.

Table 1. Activity (\%) values of paraoxonase enzyme determined in $\mathrm{HgCl}_{2}$ environment

\begin{tabular}{|c|c|c|c|c|c|c|c|c|}
\hline Heavy metal & $\begin{array}{c}\text { Tris-HCI Buffer } \\
(\mu \mathrm{L})\end{array}$ & $\begin{array}{c}\text { Supernatant } \\
\text { Solution Volume } \\
(\mu \mathrm{L})\end{array}$ & $\begin{array}{c}\text { Substrate } \\
\text { Solution Volume } \\
(\mu \mathrm{L})\end{array}$ & $\begin{array}{c}\text { Metal Solution } \\
\text { Volume } \\
(\mu \mathrm{L})\end{array}$ & $\begin{array}{c}\text { Metal Solution } \\
\text { concentration }\left(1 \times 10^{-4}\right. \\
\text { M) }\end{array}$ & $\begin{array}{c}\Delta \mathrm{OD} \\
(405 \mathrm{~nm})\end{array}$ & $\begin{array}{c}\text { Activity (U/mL } \\
\text { dak) }\end{array}$ & Activity (\%) \\
\hline \multirow{6}{*}{$\mathrm{Hg}$} & \multirow{6}{*}{50} & \multirow{6}{*}{50} & \multirow{6}{*}{50} & --- & --- & 1.1822 & 19.3910 & 100.00 \\
\hline & & & & 10 & 0.6 & 1.8862 & 30.9383 & 159.55 \\
\hline & & & & 20 & 1.1 & 1.7717 & 29.0598 & 149.86 \\
\hline & & & & 30 & 1.6 & 1.6082 & 26.3799 & 136.04 \\
\hline & & & & 40 & 2.1 & 1.4598 & 23.9443 & 123.48 \\
\hline & & & & 50 & 2.5 & 1.2603 & 20.6725 & 106.61 \\
\hline
\end{tabular}

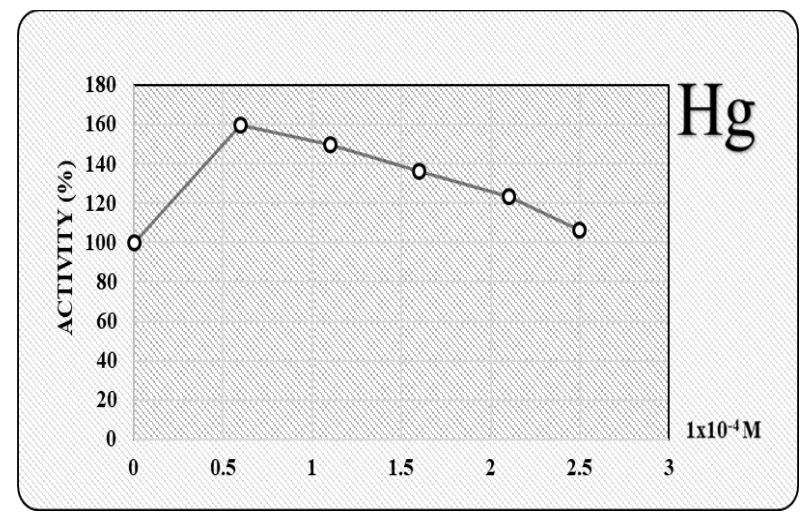

Figure 1. Activity determination for paraoxonase enzyme in $\mathrm{HgCl}_{2}$ environment
The solution concentrations and activity (\%) graph specified in Table 1 for paraoxonase enzyme in $\mathrm{HgCl}_{2}$ environment were given in Figure 1.

After determining enzyme activity, PON enzyme activity was calculated as $159.55 \%$ when added a $10 \mu \mathrm{L}-0.6 \times 10^{-4} \mathrm{M}$ $\mathrm{HgCl}_{2}$ solution to cuvettes, while enzyme activity decreased as a result of increased concentrations and was calculated as $106.61 \%$ when added a $50 \mu \mathrm{L}-2.5 \times 10^{-4} \mathrm{M} \mathrm{HgCl}_{2}$ solution. When the activity (\%) graph was examined as a result of the measurements made, it was determined that $\mathrm{Hg}^{+2}$ heavy metal ion caused a decrease in paraoxonase enzyme activity $(p<0.05)$. Paraoxonase enzyme activity $(\%)$ values obtained by using $\mathrm{CuCl}_{2}$ solutions of different concentrations $\left(0.6 \times 10^{-4}\right.$ $\left.\mathrm{M}, 1.1 \times 10^{-4} \mathrm{M}, 1.6 \times 10^{-4} \mathrm{M}, 2.1 \times 10^{-4} \mathrm{M}, 2.5 \times 10^{-4} \mathrm{M}\right)$ were given in Table 2. 
Table 2. Activity (\%) values of paraoxonase enzyme determined in $\mathrm{CuCl}_{2}$ environment

\begin{tabular}{|c|c|c|c|c|c|c|c|c|}
\hline Heavy Metal & $\begin{array}{c}\text { Tris- HCI Buffer } \\
(\mu L)\end{array}$ & $\begin{array}{l}\text { Supernatant } \\
\text { Solution } \\
\text { Volume } \\
(\mu \mathrm{L})\end{array}$ & $\begin{array}{l}\text { Substrate } \\
\text { Solution } \\
\text { Volume } \\
(\mu L)\end{array}$ & $\begin{array}{c}\text { Metal } \\
\text { Solution } \\
\text { Volume } \\
(\mu \mathrm{L})\end{array}$ & $\begin{array}{c}\text { Metal } \\
\text { Solution } \\
\text { Concentration } \\
\left(1 \times 10^{-4} \mathrm{M}\right)\end{array}$ & $\Delta O D(405 \mathrm{~nm})$ & $\begin{array}{l}\text { Activity } \\
\text { (U/mL dak) }\end{array}$ & Activity (\%) \\
\hline \multirow{6}{*}{$\mathrm{Cu}$} & \multirow{6}{*}{50} & \multirow{6}{*}{50} & \multirow{6}{*}{50} & --- & -- & 1.0730 & 17.5997 & 100.00 \\
\hline & & & & 10 & 0.6 & 1.2068 & 19.7949 & 112.49 \\
\hline & & & & 20 & 1.1 & 1.1877 & 19.4807 & 110.69 \\
\hline & & & & 30 & 1.6 & 1.1697 & 19.1864 & 109.02 \\
\hline & & & & 40 & 2.1 & 1.1657 & 19.1200 & 108.64 \\
\hline & & & & 50 & 2.5 & 1.1525 & 18.9037 & 107.41 \\
\hline
\end{tabular}

The solution concentrations and activity (\%) graph specified in Table 2 for paraoxonase enzyme in $\mathrm{CuCl}_{2}$ environment were given in Figure 2.

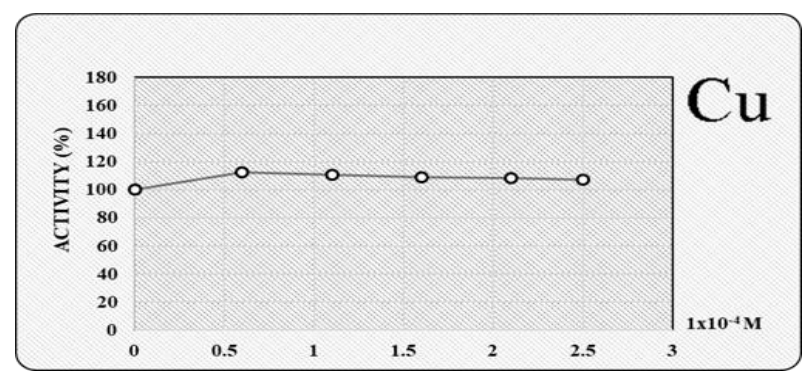

Figure 2. Activity determination for paraoxonase enzyme in $\mathrm{CuCl}_{2}$ environment
After determining enzyme activity, PON enzyme activity was calculated as $112.49 \%$ when added a $10 \mu \mathrm{L}-0.6 \times 10^{-4} \mathrm{M}$ $\mathrm{CuCl}_{2}$ solution to cuvettes, while enzyme activity decreased as a result of increased concentrations and was calculated as $107.41 \%$ when added a $50 \mu \mathrm{L}-2.5 \times 10^{-4} \mathrm{M} \mathrm{CuCl}_{2}$ solution. When the activity (\%) graph was examined as a result of the measurements made, it was determined that $\mathrm{Cu}^{+2}$ heavy metal ion caused a decrease in paraoxonase enzyme activity but there was no statistically significant difference $(p>0.05)$.

Paraoxonase enzyme activity (\%) values obtained by using $\mathrm{ZnCl}_{2}$ solutions of different concentrations $\left(0.6 \times 10^{-4} \mathrm{M}\right.$, $\left.1.1 \times 10^{-4} \mathrm{M}, 1.6 \times 10^{-4} \mathrm{M}, 2.1 \times 10^{-4} \mathrm{M}, 2.5 \times 10^{-4} \mathrm{M}\right)$ were given in Table 3.

Table 3. Activity (\%) values of paraoxonase enzyme determined in $\mathrm{ZnCl}_{2}$ environment

\begin{tabular}{|c|c|c|c|c|c|c|c|c|}
\hline $\begin{array}{l}\text { Heavy } \\
\text { Metal }\end{array}$ & $\begin{array}{c}\text { Tris- } \mathrm{HCl} \text { Buffer } \\
(\mu \mathrm{L})\end{array}$ & $\begin{array}{l}\text { Supernatant } \\
\text { Solution } \\
\text { Volume } \\
(\mu L)\end{array}$ & $\begin{array}{c}\text { Substrate } \\
\text { Solution } \\
\text { Volume } \\
(\mu \mathrm{L})\end{array}$ & $\begin{array}{c}\text { Metal Solution } \\
\text { Volume } \\
(\mu \mathrm{L})\end{array}$ & $\begin{array}{c}\text { Metal Solution } \\
\text { Concentration } \\
\left(1 \times 10^{-4} \mathrm{M}\right)\end{array}$ & $\Delta \mathrm{OD}(405 \mathrm{~nm})$ & $\begin{array}{c}\text { Activity (U/mL } \\
\text { dak) }\end{array}$ & Activity (\%) \\
\hline \multirow{6}{*}{$\mathrm{Zn}$} & \multirow{6}{*}{50} & \multirow{6}{*}{50} & \multirow{6}{*}{50} & -- & --- & 1.3021 & 21.3574 & 100.00 \\
\hline & & & & 10 & 0.6 & 1.4529 & 23.8305 & 111.58 \\
\hline & & & & 20 & 1.1 & 1.4070 & 23.0781 & 108.06 \\
\hline & & & & 30 & 1.6 & 1.3958 & 22.9073 & 107.26 \\
\hline & & & & 40 & 2.1 & 1.3676 & 22.4324 & 105.03 \\
\hline & & & & 50 & 2.5 & 1.3300 & 21.8159 & 102.15 \\
\hline
\end{tabular}

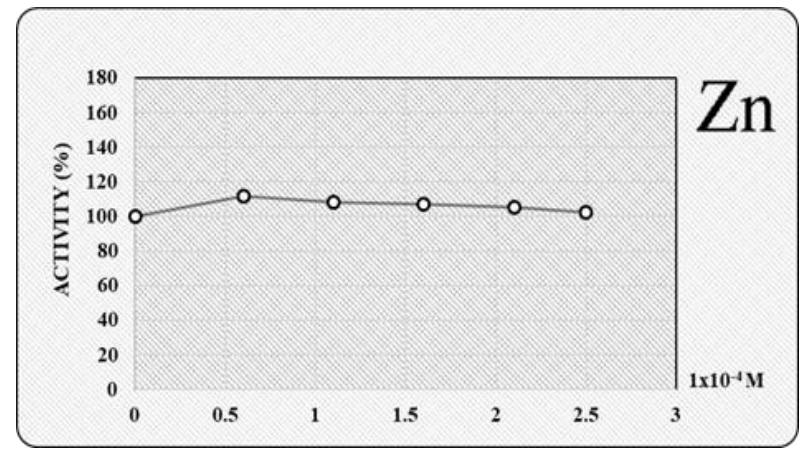

Figure 3. Activity determination for paraoxonase enzyme in $\mathrm{ZnCl}_{2}$ environment
The solution concentrations and activity (\%) graph specified in Table 3 for paraoxonase enzyme in $\mathrm{ZnCl}_{2}$ environment were given in Figure 3.

After determining enzyme activity, PON enzyme activity was calculated as $111.58 \%$ when added a $10 \mu \mathrm{L}-0.6 \times 10^{-4} \mathrm{M}$ $\mathrm{ZnCl}_{2}$ solution to cuvettes, while enzyme activity decreased as a result of increased concentrations and was calculated as $102.15 \%$ when added a $50 \mu \mathrm{L}-2.5 \times 10^{-4} \mathrm{M} \mathrm{ZnCl}_{2}$ solution. When the activity (\%) graph was examined as a result of the measurements made, it was determined that $\mathrm{Zn}^{+2}$ heavy metal ion caused a decrease in paraoxonase enzyme activity but there was no statistically significant difference $(p>0.05)$. The TOC, TAC, and OSI index values obtained as a result of the analyses were given in Table 4. 
Table 4. Total antioxidant capacity (TAC), total oxidant capacity (TOC), and oxidative stress index (OSI) values (mean values \pm standard error)

\begin{tabular}{lll}
\hline & & Mean $\pm \mathrm{SE}$ \\
\hline TAC & (mmol TroloxEquiv/L) & $0.55 \pm 0.29$ \\
TOC & $\left(\mu \mathrm{mol} \mathrm{H}_{2} \mathrm{O}_{2}\right.$ Equiv/L) & $10.72 \pm 3.52$ \\
OSI & $(\mathrm{AU})$ & $2.45 \pm 1.41$ \\
\hline
\end{tabular}

\section{DISCUSSION AND CONCLUSION}

Recently, the pollution of surface water resources by heavy metals, which is one of the common environmental pollutants, has started to increase all over the world (Uncumusaoglu et al., 2016; Mutlu and Kurnaz, 2017; Huang et al., 2020) and the level of metals in the environment has become very dangerous for the health of water and land life (Pamukoglu and Kargi, 2007). Especially, It has been shown in many studies that fish, which are among aquatic organisms, are the living group most affected from heavy metal pollution (Yilmaz et al., 2016; Aytekin and Kargın, 2019; Çoğun and Kargın, 2020). Among marine creatures, fish accumulate pollutants from the aquatic environment and therefore widely used in pollution monitoring systems of the aquatic environment (Henry et al., 2004). Due to pollution from chemicals and waters, fish are constantly exposed to heavy metals (Ashraf, 2005). An increasing heavy metal accumulation in the bodies of fish can disrupt the structure of enzymes by showing toxic effect (Mackness et al., 2000; Mackness et al., 2001). Heavy metals exhibit toxicity by complexing with organic compounds and if they bind to these groups, they can switch to the inactive enzyme form (Ekinci et al., 2007). Since PON activity is important in environmental pollution, in this study the effects of $\mathrm{Hg}^{+2}, \mathrm{Cu}^{+2}$, and $\mathrm{Zn}^{+2}$ heavy metal ions on the activity of paraoxonase enzyme, which has detoxification, antioxidant and antibacterial activity in muscle tissue of bonito ( $S$. sarda) fish was examined and the oxidative stress index of the muscle tissue at normal levels was determined.

When the effect of $\mathrm{Cu}^{+2}$ heavy metal ion on PON enzyme activity, it was determined that increasing concentrations caused a decrease in PON enzyme activity, but there was no statistically significant difference between increasing concentrations of $\mathrm{Cu}^{+2}$ heavy metal ion. Sayın et al. (2012), in a study, examined in vitro the inhibition effect of $\mathrm{Cu}^{2+}, \mathrm{Ni}^{2+}$, $\mathrm{Cd}^{2+}$, and $\mathrm{Hg}^{2+}$ metal ions on PON enzyme activity in Scyliorhinus canicula fish. $\mathrm{Cu}^{2+}, \mathrm{Ni}^{2+}, \mathrm{Cd}^{2+}$, and $\mathrm{Hg}^{2+}$ metal ions showed an inhibitory effect on this enzyme activity and were determined that the strongest effect was by $\mathrm{Cu}^{2+}$ (Sayın et al., 2012). But when the activity (\%) graphs were examined in this study, it was found that $\mathrm{Cu}^{+2}$ heavy metal ion did not cause a significant difference between enzyme activities, but $\mathrm{Hg}^{+2}$ heavy metal ion significantly caused a decrease in enzyme activity, causing a greater effect on activity. $\mathrm{Hg}$ is a metal that acts toxic by binding to thiol groups and inactivating proteins and enzymes when it enters the cell (Misra, 1992). Erdös et al. (1960), in a study, stated that $\mathrm{Hg}, \mathrm{Cu}$, and Ni salts inhibit PON1 activity at low concentration due to interacting with a thiol group at the catalytic center (Erdös et al., 1960). Therefore, $\mathrm{Hg}$ heavy metal ion is thought to inactivate the enzyme by binding to the free sulfhydryl (thiol) group in the cysteine at the 284 th position of the PON enzyme. During the oxidation of $\mathrm{Cu}^{+1} / \mathrm{Cu}^{+2}$ ions, it has also been reported that it may be responsible for the partial inactivation of PON, replacing the $\mathrm{Ca}$ ion required for PON's paraoxonase activity (Aviram, 1999). In this study, when the activity (\%) graph was examined, It was determined that the $\mathrm{Cu}^{+2}$ heavy metal ion acted in this way, causing a partial decrease in paraoxonase enzyme activity but there was no significant difference between statistically measured activities.

When the effect of $\mathrm{Zn}^{+2}$ heavy metal ion on PON enzyme activity was examined, it was determined that increasing concentrations caused a decrease in PON enzyme activity, but there was no statistically significant difference between increasing concentrations of $\mathrm{Zn}^{+2}$ heavy metal ion. In a study investigating the effect of zinc on PON enzyme activity in fish, plasma PON activity of Capoeta capoeta fish kept in tanks containing 5 and $10 \mathrm{mg} / \mathrm{L} \mathrm{ZnSO}_{4}$ for 10 days decreased compared to the control group. They reported that this decrease in PON enzyme activity may be due to the absorption relationship between $\mathrm{Ca}^{+2}$ and $\mathrm{Zn}^{+2}$ cations (Deveci et al., 2015). In this study, when the activity graph of the $\mathrm{Zn}^{+2}$ heavy metal ion was examined, it was observed that it caused a decrease in PON enzyme activity, and this decrease in activity was thought to be due to the absorption relationship between $\mathrm{Ca}^{+2} / \mathrm{Zn}^{+2}$ ions. Because the $\mathrm{Ca}^{+2}$ ions required for the stability and activity of the PON enzyme due to $\mathrm{HDL}$ in plasma are directly related to the absorption of $\mathrm{Zn}^{+2}$ ions (Babacan et al., 2011; Cicik, 2003). Also, $\mathrm{Zn}$ is taken by an apical $\mathrm{Ca}^{+2}$ channel found in mitochondrial-rich ion carrier cells in the gills of fish (Bury et al., 2003; Zhang and Wang, 2006).

It was observed that $\mathrm{Hg}^{+2}$ heavy metal ion showed a statistically significant decrease in PON enzyme activity compared to $\mathrm{Cu}^{+2}$ and $\mathrm{Zn}^{+2}$ ions due to increasing concentrations and inhibited the enzyme. Especially when enzyme activities were compared, it was determined that there were significant differences between the $0.6 \times 10^{-4} \mathrm{M}$ and 2.1-2.5 $\times 10^{-4} \mathrm{M}$ samples used and between $1.1 \times 10^{-4} \mathrm{M}$ and $2.5 \times 10^{-4} \mathrm{M}$ samples. According to the results obtained, it was seen that the $\mathrm{Hg}^{+2}$ heavy metal ion inhibited by showing more effect compared to $\mathrm{Cu}^{+2}$ and $\mathrm{Zn}^{+2}$ ions on enzyme activity. In a study examined the effect of different metals on paraoxonase enzyme activity in carp (Cyprinus carpio) fish, it was determined that $\mathrm{Co}, \mathrm{Hg}, \mathrm{Cu}$, and $\mathrm{Cd}$ heavy metals inhibited different levels of PON activity (Beyaztaş et al., 2007).

In another study in scaly carp (C. carpio) fish, the effect of malathion, which is known to be toxic such as heavy metals on paraoxonase and arylesterase enzyme activities were researched and it was observed that PON activity decreased due to increasing concentrations of malathion (KIlıç and Yonar, 2017). In a study using the chromium oxide $\left(\mathrm{CrO}_{3}\right)$ 
form of chromium, a heavy metal such as copper, mercury and zinc, it was determined that chromium applied at concentrations of 15,30 and $60 \mathrm{ppb}$ for 28 days reduced the activity of carp (C. carpio) serum PON (Yonar et al., 2012).

In a study conducted in bonito ( $S$. sarda) fish, it was examined the effect of some heavy metals on glutathione transferase enzyme, which has detoxification and antioxidant properties such as the PON enzyme. Güller et al. (2014), in this study, the effects of $\mathrm{Pb}^{2+}, \mathrm{Cr}^{2+}, \mathrm{Fe}^{3+} \mathrm{Ag}^{+}, \mathrm{Cu}^{2+}, \mathrm{Cd}^{2+}$, and $\mathrm{Zn}^{2+}$ metal ions on the enzyme activity were examined and it was reported that $\mathrm{Cu}$ ion showed the strongest inhibitor effect and, $\mathrm{Zn}$ ion showed weakest inhibitor effect (Güler et al., 2014). When the activity (\%) graphs were examined also in our study, it was found that $\mathrm{Zn}$ heavy metal ion caused a more significant decrease in PON enzyme activity compared to Cu heavy metal ion.

Besides studies carried out among fish, in the studies also carried out in rats, humans, bull, and sheep, the effect of heavy metals on PON enzyme activity was investigated. Pla et al. (2007), in a study, examined the effects of some metal ions on PON1 enzyme activity purified from rat liver. In the present study they have done, inhibition effects of $\mathrm{Mn}^{+}, \mathrm{Cu}^{+2}$, $\mathrm{Hg}^{+2}$ ve $\mathrm{Co}^{+2}$ heavy metal ions were determined and it was determined that $\mathrm{Hg}^{+2}$ heavy metal ion was the strongest inhibitor and $\mathrm{Cu}^{+2}$ ion was the weakest inhibitor for PON1 (Pla et al., 2007). In this study, when the activity (\%) graphs were examined, it was determined that the inhibitor effect of $\mathrm{Hg}^{+2}$ ion on the enzyme activity more than the effect of $\mathrm{Cu}^{+2}$ ion. When looked the effect of $\mathrm{Hg}^{+2}$ and $\mathrm{Cu}^{+2}$ heavy metal ions on PON enzyme activity studied in bonito ( $S$. sarda) fish, it is seen that it causes a decrease in enzyme activity similar to the PON1 enzyme activity in rats. Samra et al. (2010), examined the in vitro inhibitor effects of some metal ions, at $1.0 \mathrm{mM}$ concentration on human PON1 enzyme activity. It was determined that $\mathrm{Mg}^{+2}$ and $\mathrm{Mn}^{+2}$ ions did not show any effect on human PON1 enzyme activity, $\mathrm{Pb}^{+2}, \mathrm{Co}^{+2}$, and $\mathrm{Zn}^{+2}$ ions decreased the activity, while $\mathrm{Ni}^{+2}, \mathrm{Cd}^{+2}$, and $\mathrm{Cu}^{+2}$ ions inhibited the PON1 enzyme activity (Samra et al., 2010). Dedeoğlu et al. (2014), in a study, determined changes occurring in PON1 enzyme activity purified from bull semen in the presence of $\mathrm{Cu}^{+2}, \mathrm{Mn}^{+2}, \mathrm{Cd}^{+2}, \mathrm{Zn}^{+2}, \mathrm{Ni}^{+2}$, and $\mathrm{Pb}^{+2}$ heavy metal ions in different cuvette concentrations. While $\mathrm{Cd}^{+2}$ ions increased PON1 activity, other heavy metal ions were found to inhibit PON1 at micromolar levels (Dedeoğlu et al., 2014). It was determined that $\mathrm{Cu}^{+2}$ and $\mathrm{Zn}^{+2}$ heavy metal ions used in this study also caused at low levels decrease of PON enzyme activity in bonito ( $S$. sarda) fish but there was no statistically significant difference. Therefore, it is seen that $\mathrm{Cu}$ and $\mathrm{Zn}$ heavy metal ions affect PON enzyme activity studied in bonito (S. sarda) fish, similar to that of human PON1 enzyme and PON1 enzyme activity purified from bull semen. Erol et al. (2013), in another study, examined the effect of some metal ions on PON1 enzyme activity purified from blood samples taken from Merino and Kivircik sheep breeds. It was determined that $\mathrm{Mn}^{+2}, \mathrm{Hg}^{+2}, \mathrm{Co}^{+2}, \mathrm{Cd}^{+2}, \mathrm{Ni}^{+2}$, and $\mathrm{Cu}^{+2}$ metal ions showed different levels of inhibition effect on PON enzyme activity and $\mathrm{Cu}^{+2}$ heavy metal ion caused strongest inhibitor effect for PON (Erol et al., 2013). When examined the effects of heavy metal ions used in this study on PON enzyme activity in bonito ( $S$. sarda) fish, it is seen that $\mathrm{Cu}^{+2}$ metal ion caused a partial decrease in the enzyme activity compared to other heavy metal ions $\left(\mathrm{Hg}^{+2}, \mathrm{Zn}^{+2}\right)$ used in the study. Therefore, it is seen that the $\mathrm{Cu}^{+2}$ heavy metal ion caused a decrease at different levels of PON enzyme activity in Merino and Kivircik sheep breeds by the PON enzyme of bonito (S. sarda) fish.

In the study, the effect of $\mathrm{Hg}^{+2}, \mathrm{Cu}^{+2}$, and $\mathrm{Zn}^{+2}$ heavy metal ions was researched on paraoxonase enzyme activity, which an antioxidant enzyme in muscle tissue of bonito ( $S$. sarda) fish, and it was found $\mathrm{Cu}^{+2}, \mathrm{Zn}^{+2}$ ions caused a statistically insignificant decrease in enzyme activity. It is thought that the inhibitory effect of $\mathrm{Cu}$ and $\mathrm{Zn}$ ions, which are present in excess amount in the environment, on the PON enzyme may be due to the substitution of $\mathrm{Ca}$ ions, which are the cofactor of the enzyme. Therefore, it is thought of these ions cause a decrease in activity by causing inhibition of enzymatic activity. It is thought that $\mathrm{Zn}^{+2}$ and $\mathrm{Cu}^{+2}$ ions to be used in higher concentrations in studies where the effects of heavy metals on PON enzyme activity will be investigated, may cause a significant decrease in enzyme activity. $\mathrm{Hg}^{+2}$ heavy metal ion is thought to inhibit the enzyme activity and show its inhibitory effect on the enzyme by binding to the free sulfhydryl (thiol) group in the cysteine at the 284 th position of the PON enzyme. It is thought that controlled experimental studies may be conducted to investigate the effects of heavy metals taken in higher concentrations on TOC, TAC and PON enzyme activity and our study may also create an example.

\section{ACKNOWLEDGEMENTS}

The authors thank the support provided by the Ondokuz Mayıs University Scientific Research Projects Commission Presidency with the Project number PYO.VET.1904.19.011. 


\section{REFERENCES}

Ağcasulu, Ö. (2007). Investigation of accumulation of heavy metals in tissues of Capoeta tinca (Heckel, 1843) living in çeltikçe stream of sakarya rıver. Gazi University Institute of Science, MS Thesis, Ankara, Turkey. (In Turkish).

Ashraf, W. (2005). Accumulation of heavy metals in kidney and heart tissues of Epinephelus microdon fish from the Arabian Gulf. Environmental Monitoring and Assessment, 101(1-3), 311-316. DOI: 10.1007/s10661-005-0298-4

Aviram, M. (1999). Does paraoxonase play a role in susceptibility to cardiovascular disease? Moleculer Medicine Today, 5(9), 381-386. DOI: 10.1016/S1357-4310(99)01546-4

Aytekin, T. \& Kargin, F. (2019). Effect of copper on G6PD activity in the liver, gill, kidney and muscle tissues of Oreochromis niloticus. Journal of Anatolian Environmental and Animal Sciences, 4(2), 60-63. DOI: 10.35229/jaes.537019

Babacan, F., Isık, B. \& Bingol, B. (2011). Changes in serum paraoxonase activity, calcium and lipid profiles in pre-eclampsia, a preliminary study. Journal of Turkish Society of Obstetrics and Gynecology, 8(3), 169-174. DOI: 10.5505/tjod.2011.24540

Baillie, T.A., Moldeus, P., Mason, R.P. \& Younes, M. (1993). Enzymes interacting with organophosphorus compounds. Shannon: Elsevier Scientific Publishers Ireland Ltd.

Beyaztaş, S., Türker, D., Sinan, S. \& Arslan, O. (2007). Cyprinus carpio paraoksonaz enziminin bazı ağır metallerle inhibisyon etkisinin incelenmesi. 21. Ulusal Kimya Kongresi (pp. 23-27). Malatya, Türkiye.

Broomfield, CA. \& Ford, K.W. (1991). Hydrolysis of nerve gasses by plasma enzymes. Proceedings of the 3rd International Meeting on Cholinesterases (pp. 167). La Grande-Motte, France.

Bury, N.R., Walker, P.A. \& Glover, C.N. (2003). Nutritive metal uptake in teleost fish. Journal of Experimental Biology, 206, 11-23. DOI: 10.1242/jeb.00068

Carey, J.N.G., Shih, D.M., Hama, S.Y., Villa, N., Navab, M. \& Reddy, T.S. (2005). The paraoxonase gene family and atherosclerosis. Free Radical Biology and Medicine, 38(2), 153-163.

DOI: 10.1016/j.freeradbiomed.2004.09.035

Cicik, B. (2003). The effects of copper-zinc interaction on the accumulation of metals in liver, gill and muscle tissues of common carp (Cyprinus carpio L.) (in Turkish with English abstract). Ekoloji Çevre Dergisi, 12(48), 3236

Coppock, R.W. \& Nation, P.N. (2007). Aquatic toxicology. In C. Ramsh, (Ed.), Veterinary toxicology: Basic and Critical Principles. Elsevier Inc (pp. 709713). Amsterdam, Netherlands.

Costa, L.G., Li, W.F., Richter, R.J., Shih, D.M., Lusis, A. \& Furlong, C.E. (1999). The role of paraoxonase (PON1) in the detoxification of organophosphates and its human polymorphism. Chemico-Biological interactions, 119-120, 429-438. DOI: 10.1016/s0009-2797(99)00055-1

Çoğun, H.Y. \& Kargın, F. (2020). Copper accumulation and $\mathrm{Na} / \mathrm{K}$ ion levels in gill tissue of Cyprinus carpio (in Turkish with English abstract). Journal of Anatolian Environmental and Animal Sciences, 5(3), 313-317. DOI: 10.35229 jjaes.749347

Deakin, S. \& James, R.W. (2004). Genetic and environmental factors modulating serum concentrations and activities of the antioxidant enzyme paraoxonase-I. Clinical Science, 107(5), 435-447. DOI: $10.1042 / C S 20040187$

Dedeoğlu, N., Arslan, M. \& Erzengin, M. (2014). Purification of holstein bull semen paraoxonase 1 (PON1) by hydrophobic interaction chromatography and investigation of Its inhibition kinetics by heavy metals. Biological Trace Element Research, 158(1), 29-35. DOI: 10.1007/s12011-014-9916-8

Deveci, H.A., Kaya, I., Yılmaz, M. \& Karapehlivan, M. (2015). Effect of zinc sulphate on the levels of plasma paraoxonase activity, total oxidant and high density lipoprotein of transcaucasian barb (Capoeta capoeta Guldenstaedt, 1773). Fresenius Environmental Bulletin, 24(9), 27322735.
Dökmeci, İ. (2001). Zehirler ve zehirlenmeler. Toksikoloji. 3. Baskı, Nobel Tıp Kitabevi (pp. 249-692). İstanbul, Türkiye.

Eckerson, H.W., Wyte, C.M. \& La Du, B.N. (1983). The human serum paraoxonase/arylesterase polymorphism. American Journal of Human Genetics, 35(6), 1126-1138.

Ekinci, D., Beydemir, S. \& Küfrevioglu, O.I. (2007). In vitro inhibitory effects of some heavy metals on human erythrocyte carbonic anhydrases. Journal of Enzyme Inhibition and Medicinal Chemistry, 22(6), 745-750. DOI: $10.1080 / 14756360601176048$

Elana, T., Elana, M., Magdalena, G., Isabel, L. \& Ana, M.P. (2006). Effects of caloric restriction and gender on rat serum paraoxonase 1 activity. The Journal of Nutritional Biochemistry, 17(3), 197-203. DOI: 10.1016/j.jnutbio.2005.07.004

Erdös, E.G., Debay, C.R. \& Westerman, M.P. (1960). Arylesterases in blood: Effect of calcium and inhibitors. Biochemical Pharmacology, 5(3), 173186. DOI: 10.1016/0006-2952(60)90061-7

Erel, O. (2005). A new automated colorimetric method for measuring total oxidant status. Clinical Biochemistry, 38(12), 1103-1111. DOI: 10.1016/j.clinbiochem.2005.08.008

Erel, O. (2004). A novel automated direct measurement method for total antioxidant capacity using a new generation, more stable abts radical cation. Clinical Biochemistry, 37(4), 277-285.

DOI: 10.1016/j.clinbiochem.2003.11.015

Erol K., Gençer, N., Arslan, M. \& Arslan, O. (2013). Purification, characterization, and investigation of in vitro inhibition by metals of paraoxonase from different sheep breeds. Artifical Cells, Nanomedic, and Biotechnology, 41(2), 125-130. DOI: $10.3109 / 10731199.2012 .696065$

Gülcü, F. \& Gürsu, M.F. (2003). The standardization of paraoxonase and arylesterase activity measurements (in Turkish with English abstract). Turkish Journal of Biochemistry, 28(2), 45-49.

Güller, U., Taşer, P., Çiftci, M. \& Küfrevioğlu, Ö.l. (2014). Purification of glutathione s-transferase from bonito (Sarda sarda) liver and Investigation of metal ıns effects on enzyme activity. Hacettepe Journal of Biology and Chemistry, 42(3), 435-442.

Henry, F., Amara, R., Courcot, L., Lacouture, D. \& Bertho, M.L. (2004). Heavy metals in four fish species from the French coast of the Eastern English Channel and Southern Bight of North Sea. Environment International 30(5), 675-683. DOI: 10.1016/j.envint.2003.12.007

$\mathrm{Hu}, \mathrm{H}$. (2002). Human health and heavy metals exposure. In McCally M (ed.), Life support: The environment and human health. MIT press (pp. 65). Cambridge, Massachusetts Londan, England.

Huang, Z., Liu, C., Zhao, X., Dong, J. \& Zheng B. (2020). Risk assessment of heavy metals in the surface sediment at the drinking water source of the Xiangjiang River in South China. Environmental Sciences Europe, 32(23), 1-9. DOI: 10.1186/s12302-020-00305-w

Ikuta, K.A. (1985). Comparison on heavy metal contents between Batillus cornutus and Babylonia japonica. Bulletin of Faculty Agriculture, 32(1), 79-84.

Kahvecioğlu, Ö., Kartal, G., Güven, A. \& Timur, S. (2003). Metallerin çevresel etkileri -I (in Turkish). Metalurii Dergisi, 1, 12.

Kalay, M. \& Erdem, C. (1995). Bakırın Tilapia nilotica'da karaciğer, böbrek, solungaç, kas, beyin ve kan dokularındaki birikimi ile bazı kan parametreleri üzerine etkileri. Turkish Journal of Zoology, 19, 27-33.

Kaptan, H. (2014). Eğirdir Gölü (Isparta)'nün suyunda, sedimentinde ve gölde yaşayan sazan (Cyprinus carpio L., 1758)'in bazı doku ve organlarındaki ağır metal düzeylerinin belirlenmesi. Süleyman Demirel Üniversitesi, Yüksek Lisans Tezi, Isparta, Turkey. (In Turkish).

Kaya, S. \& Akar F (ed.). (2002). Metaller, diğer organik maddeler ve radyo etkin Maddeler. Veteriner Hekimliğinde Toksikoloji, 2.baskı, Medisan (pp 207-250). Ankara, Türkiye.

Kilıç, T. \& Yonar, M.E. (2017). Investigation of effect of malathion on paraoxonase and arylesterase enzyme activities in scaly carp (Cyprinus 
carpio) (in Turkish with English abstract). Firat Üniversitesi Veteriner Dergisi, 31(2), 87-92.

La Du, B.N., Aviram, M., Billecke, S., Navab, M., Primo-Parmo, S., Sorenson, R.C. \& Standiford, T.J. (1999). On the physioogical role(s) of the paraoxonases. Chemico-Biological Interactions, 119-120, 379-388.

Mackness, B., Davies, G.K., Turkei, W., Lee, E., Roberts, D.H, Hill, E., Roberts, C., Duringhton, P.N. \& Mackness, M.I. (2001). Paraoxonase status in coronary heart disease. Arterosclerosis Thrombosis and Vascular Biology, 21(9), 1451-1457. DOI: 10.1161/hq0901.094247

Mackness, M.l., Mackness, B., Durrington, P.N., Connelly, P.W. \& Hegele, R.A. (1996). Paraoxonase: Biochemistry, genetics and relationship to plasma lipoproteins. Current Opinion in Lipidology, 7(2), 69-76. DOI: 10.1097/00041433-199604000-00004

Mackness, M.I., Mackness, B. \& Durrington, P.N. (2000). Paraoxonase and coronary heart disease. Atherosclerosis Supplements, 3(4), 49-55. DOI: 10.1016/s1567-5688(02)00046-6

Memişoğulları, R.\& Orhan, N. (2010). Paraoxonase and Cancer (in Turkish with English abstract). Konuralp Tip Dergisi, 2(2), 22-26.

Misra, T.K. (1992). Bacterial resistance to inorganic mercury salts and organomercurials. Plasmid, 27(1), 4-16. DOI: 10.1016/0147-619X(92)90002-R

Mutlu, E. \& Kurnaz, A. (2017). Determination of seasonal variations of heavy metals and physicochemical parameters in Sakız Pond (KastamonuTurkey). Fresenius Environmental Bulletin, 26(4), 2807-2816.

Pamukoglu, Y.M. \& Kargi, F. (2007). Copper (II) iontoxicity in activated sludge processes as function of operating parameters. Enzyme and Microbial Technology, 40(5), 1228-1233. DOI: 10.1016/j.enzmictec.2006.09.005

Pla, A., Rodrigo, L., Hern'andez, A.F, Gil, F. \& Lopez, O. (2007). Effect of metal ions and calcium on purified PON1 and PON3 from rat liver. Chemico-Biological Interaction, 167(1), 63-70. DOI: 10.1016/j.cbi.2007.01.006

Primo-Parma, S.L., Sorenson, R.C., Teiber, J. \& La Du, B.N. (1996). The human serum paraoxonase/arylesterase gene (PON1) is one member of multigene family. Genomics, 33(3), 498-507.

Prior, R.L. \& Cao, G. (1999). In vivo total antioxidant capacity: comparison of different analytical methods1. Free Radical Biology Medicine, 27(11-12), 1173-1181. DOI: 10.1016/s0891-5849(99)00203-8

Sağmanlıgil, H. (1994). Çevre sağlığı ve kimyasalların riski (in Turkish). Yeni Yüzyıl Üniversitesi Veteriner Fakültesi Dergisi, 5(1-2), 57-64.
Samra, Z.Q., Shabir, S., Rehmat, Z., Zaman, M., Nazir, A., Dar, N. \& Athar, M.A. (2010). Synthesis of cholesterol-conjugated magnetic nanoparticles for purification of human paraoxonase 1. Applied Biochemistry Biotechnology, 162, 671-686. DOI: 10.1007/s12010-009-8840-4

Sayın, D., Cakır, D.T., Gençer, N. \& Arslan, O. (2012). Effects of some metals on paraoxonase activity from shark (Scyliorhinus canicula). Journal of Enzyme Inhibition and Medicinal Chemistry, 27(4), 595-598. DOI: $10.3109 / 14756366.2011 .604320$

Seven, T., Can, B., Darende, N.B. \& Ocak, S. (2018). Heavy metals pollution in air and soil (in Turkish with English abstract). Ulusal Çevre Bilimleri Araştırma Dergisi, 1(2), 91-103.

Sorenson, R.C., Primo-Parmo, S.L., Kuo, C.L., Adkins, S., Lockridge, O. \& La Du, B.N. (1995). Reconsideration of the catalytic center and mechanism of mammalian paraoxonase/arylesterase. Proceeding of the National Academic Sciences, USA, 92(16), 7187-7191. DOI: 10.1073/pnas.92.16.7187

Teiber, J.F., Billecke, S.S., La Du, BN. \& Draganov, D.I. (2007). Estrogen esters as substrates for human paraoxonases. Archives of Biochemistry Biophysics, 461(2), 24-29. DOI: 10.1016/j.abb.2007.02.015

Uncumusaoglu, A., Sengul, U. \& Akkan, T. (2016). Environmental contamination of heavy metals in the Yaglidere Stream (Giresun), Southeastern Black Sea. Fresenius Environmental Bulletin, 25(12), 5492-5498.

Vural, H. (1993). Ağır metal iyonlarının gıdalarda oluşturduğu kirlilikler. Ekoloji Dergisi, 8, 3-8.

Yazkan, M., Özdemir, F. \& Gölükcü, M. (2004). Cu, Zn, Pb and Cd contents in some molluscs and crustacean in the Gulf of Antalya (in Turkish with English abstract). Turkish Journal of Veterinary and Animal Sciences, 28, 95-100.

Yilmaz, M., Teber, C., Akkan, T., Er, C. \& Kariptas, E. (2016). Determination of heavy metal levels in different tissues of tench (Tinca tinca L., 1758) from Sıddıklı Küçükboğaz dam lake (Kirsehir), Turkey. Fresenius Environmental Bulletin, 25(6), 1972-1977.

Yonar, M.E., Yonar, S.M., Çoban, M.Z. \& Eroğlu, M. (2012). The effect of propolis on serum paraoxonase and arylesterase enzyme activies in Cyprinus carpio during chromium exposure. Fresenius Environmental Bulletin, 21 (6), 1399-1402.

Zhang, L. \& Wang, W. (2006). Alteration of dissolved cadmium and zinc uptake kinetics by metal pre-exposure in the black sea bream (Acanthopagrus schlegeli). Environmental Toxicology and Chemistry, 25(5), 1312-1321. DOI: 10.1897/05-262r.1 